Article

\title{
Series Connected Photovoltaic Cells-Modelling and Analysis
}

\author{
Anas Al Tarabsheh ${ }^{1,2, *}$, Muhammad Akmal ${ }^{1}$ and Mohammed Ghazal ${ }^{1}$ \\ 1 Electrical and Computer Engineering Department, Abu Dhabi University, 59911 Abu Dhabi, UAE; \\ muhammad.akmal@adu.ac.ae (M.A.); mohammed.ghazal@adu.ac.ae (M.G.) \\ 2 Electrical Engineering Department, the Hashemite University, 13115 Zarqa, Jordan \\ * Correspondence: anas.altarabsheh@adu.ac.ae; Tel.: +971-501-5226
}

Academic Editors: Jiawei Gong, Qiquan Qiao, Zhengping Zhou, Tingting Xu, Mao Liang and Wenfeng Zhang Received: 11 January 2017; Accepted: 28 February 2017; Published: 7 March 2017

\begin{abstract}
As solar energy costs continue to drop, the number of large-scale deployment projects increases, and the need for different analysis models for photovoltaic (PV) modules in both academia and industry rises. This paper proposes a modified equivalent-circuit model for PV modules. A PV module comprises several series-connected PV cells, to generate more electrical power, where each PV cell has an internal shunt resistance. Our proposed model simplifies the standard one-diode equivalent-circuit (SEC) model by removing the shunt resistance and including its effect on the diode part of the circuit, while retaining the original model accuracy. Our proposed equivalent circuit, called here a modified SEC (MSEC), has less number of circuit elements. All of the PV cells are assumed operating under the same ambient conditions where they share the same electric voltage and current values. To ensure the simplification did not come at a reduction in the accuracy of the SEC model, we validate our MSEC model by simulating both under the same conditions, calculate, and compare their current/voltage $(I / V)$ characteristics. Our results validate the accuracy of our model with the difference between the two models falling below $1 \%$. Therefore, the proposed model can be adopted as an alternative representation of the equivalent circuit for PV cells and modules.
\end{abstract}

Keywords: photovoltaic module; equivalent-circuit; current/voltage characteristics

\section{Introduction}

Photovoltaic (PV) cells absorb light of appropriate photon energy as it strikes its surface, leading to energy-carrying electrons to be released to circulate in a closed loop circuit through an external load to supply it with energy. The resulting electric current continues as long as the light continues to strike the surface of the PV cell. The load has to have an optimum value where the generated electric power of the PV cell is the maximum [1,2]. A PV module comprises a number of series-connected PV cells in order to amass more energy than that which is converted by a single PV cell. Researchers and manufacturers of PV modules alike strive to achieve the highest possible electrical efficiency by characterizing and optimizing the fabrication parameters of the PV cells. One of the most important characterization methods applied for PV cells is the current/voltage $(I / V)$ characteristic, which is a key in deriving important electrical parameters of the PV modules [3,4]. For example, these parameters include the module's current $\left(I_{\mathrm{m}}\right)$, voltage $\left(V_{\mathrm{m}}\right)$ at maximum-power point, open-circuit voltage $\left(V_{\mathrm{oc}}\right)$, short-circuit current $\left(I_{\mathrm{sc}}\right)$, fill factor $(F F)$, and efficiency $(\eta)$. Figure 1 shows the current/voltage $(I / V)$ characteristics of a PV module whose electrical parameters are depicted on the same figure. 


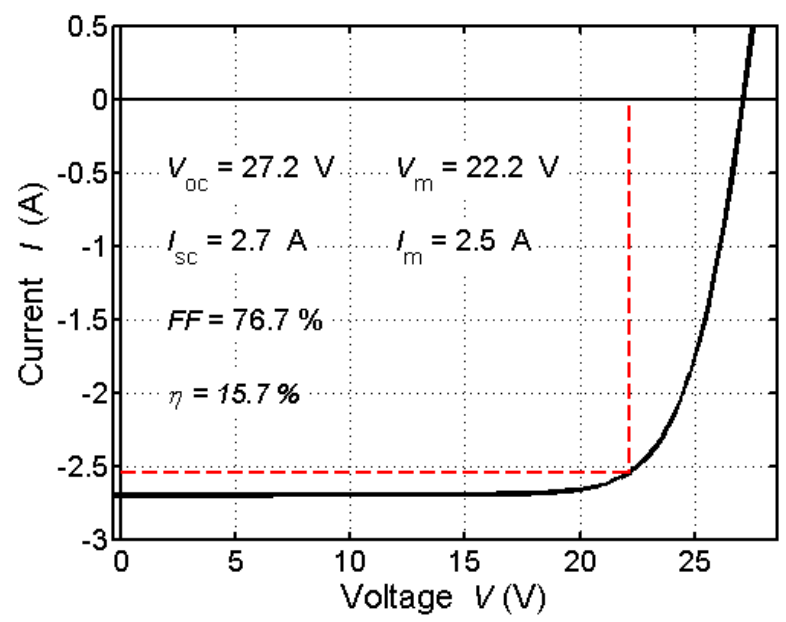

Figure 1. Current/voltage $(I / V)$ characteristics of a PV module highlighting the key electrical parameters.

Several works in the past investigated different models for PV cells [5-13]. The interest of the researchers and manufacturers is driven by a need to optimize new technologies and to study their behavior in different contexts and under varying conditions. Additionally, accurate and simplified models for PV modules are cornerstones for the development of reliable and robust simulation technology to aid in design and manufacturing. Recent advances in simulation methodologies, availability of software, and technical developments have made simulation one of the most widely used and accepted tools in systems analysis and operations research. The work of Romero et al. [14] presented, for the first time, an exact analytical solution for the two-diode circuit of PV cells based on the Lambert W-functions. Additionally, Pozo et al. [15] solved the two-diode circuit model that has a transcendental equation system by numerical techniques. A novel simplifying method was investigated by Ding et al. [16] to simulate the behavior of the $I / V$ characteristic of PV modules by applying three parameters using MATLAB Simulink blocks, while other researchers built a one-diode model using blocks from the Simulink library [17-20]. Santos et al. presented an accurate model based on the Shockley equation for simulating photovoltaic modules. This modeling tool allows the analysis of the behavior of electrical characteristics in accordance with environmental changes, such as temperature and irradiance [21]. Wang et al. proposed a new piecewise linear circuit model for PV cells and modules based on a series-structure equivalent circuit. This proposed model is different from the parallel-structure circuit model that has been extensively used in PV system analysis and simulation for a few years [22].

\section{Modified Standard Equivalent-Circuit (MSEC)}

In this work, we derive our simplified model from the standard equivalent-circuit (SEC), shown in Figure 2a, of one PV cell [23]. The model comprises a current source, a diode, and parasitic resistors. The parallel (or shunt) resistance $\left(R_{\mathrm{p}}\right)$ reflects the leakage occurrence through the PN-junction of the PV cell [24], whereas $R_{\mathrm{S}}$ represents the electrical losses of the cell's surface and bulk. The current/voltage $(I / V)$ characteristics can then be written as given in Equation (1) [25-27]:

$$
\begin{aligned}
I & =I_{D}+\frac{V-I R_{s}}{R_{p}}-I_{p h}, \\
& =I_{S}\left(\exp \left[\frac{V-I R_{s}}{n V_{t}}\right]-1\right)+\frac{V-I R_{s}}{R_{p}}-I_{p h},
\end{aligned}
$$

where $I_{D}$ is the diode's (PN-junction) current, $I_{s}$ is the reverse-saturation current, $V_{t}$ is the thermal voltage [28] (equal to $25.9 \mathrm{mV}$ at $300 \mathrm{~K}$ ), $n$ is the ideality factor [29] that depends on the exact recombination mechanism, and $I_{p h}$ is the maximum generated current (short-circuit current) from the 
PV cell. Figure $2 \mathrm{~b}$ shows the standard equivalent model (SEC) of $N$ identical series-connected PV cells operating under the same ambient conditions.

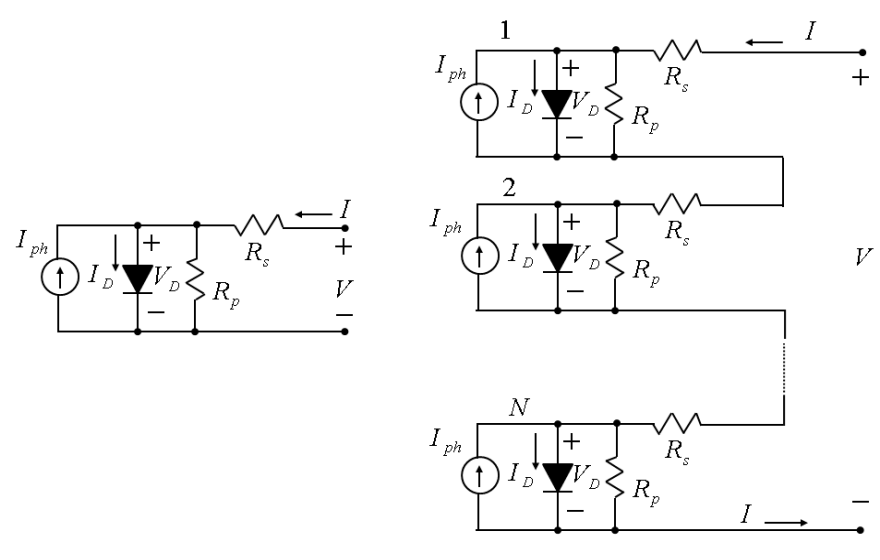

(a)

(b)

Figure 2. Standard equivalent-circuit (SEC) of (a) one PV cell and (b) $N$ series-connected PV cells.

Our ultimate objective in this work is to further simplify the SEC of $N$ series-connected PV cells to increase its utility. To integrate the circuit elements of each PV cell, we propose to modify the SEC of the PV cell as shown in Figure 3 which directly simplifies each PV cell where the current/voltage $(I / V)$ equation resulting from Figure 2 should be kept identical to that of the circuit shown in Figure 3. The resulting series resistance $R_{\mathrm{sx}}$ shown in Figure 3a is not linear since it depends on the current, as will be shown in the upcoming systems of equations.

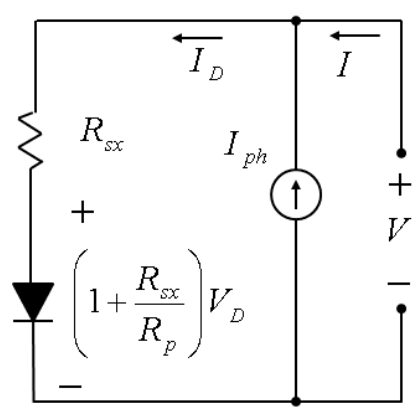

(a)

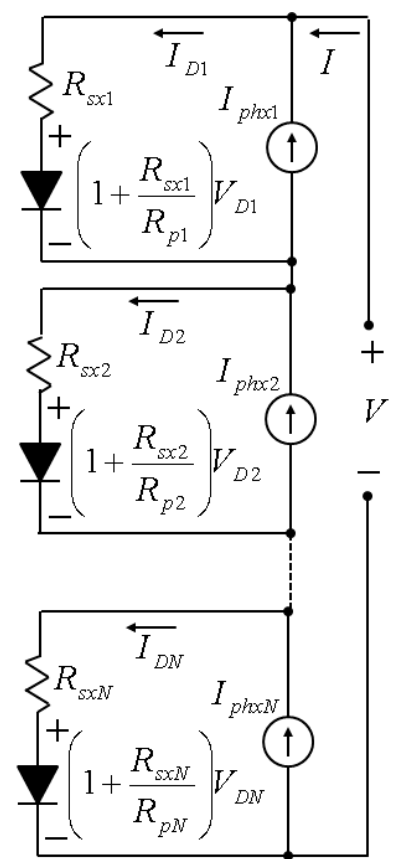

(b)

Figure 3. Modified standard equivalent-circuit models of (a) one PV cell and (b) N-series connected PV cells.

From Figures 2 and 3, the PV cell's output voltage and current are expressed according to the SEC (Equation (2)) and MSEC (Equation (3)) models, respectively, as: 


$$
V=I R_{s}+\left(I+I_{p h}-I_{D}\right) R_{p}
$$

where $I=\frac{V-V_{D}}{R_{s}}$ :

$$
V=\left(I+I_{p h x}\right) R_{s x}+\left(I+I_{p h x}-I_{D}\right) R_{p}
$$

where $I=\frac{V-V_{D}}{R_{s x}}-I_{p h x}$.

By equating the similar terms of Equations (2) and (3), and assuming that $I_{\mathrm{phx}}=I_{\mathrm{ph}}$, we find the voltage across the PV cell as:

$$
V=I_{D} R_{s x}+\left(1+\frac{R_{s x}}{R_{p}}\right) V_{D}
$$

Figure 3a shows the modified equivalent-circuit (MSEC) of $N$ series-connected PV cells where it has one series resistance $R_{s x}=\frac{I}{\left(I+I_{p h x}\right)} R_{s}$ while the parallel resistance is included in the equivalent diode's voltage drop $\left(1+R_{s x} / R_{p}\right) V_{D}$.

All of the PV cells are assumed operating under the same conditions and, thus, share the same electric voltage and current values. Therefore, the voltage and the current of the PV module are expressed as:

$$
\begin{gathered}
V=N I_{D} R_{s x}+\left(1+\frac{R_{s x}}{R_{p}}\right) N V_{D} \\
I=I_{S}\left(\exp \left(\frac{V-I_{D} N R_{s x}}{N\left(1+\frac{R_{s x}}{R_{p}}\right) n V_{t}}\right)-1\right)-I_{p h}
\end{gathered}
$$

The standard current/voltage equation for a PV module is:

$$
I=I_{s}\left[\exp \left\{\frac{\frac{V}{N}-I R_{s}}{n V_{t}}\right\}-1\right]+\frac{\frac{V}{N}-I R_{s}}{R_{p}}-I_{p h}
$$

where the saturation current density $I_{S}$ is temperature dependent and is expressed as:

$$
I_{s}=I_{s 0}\left(\frac{T}{300}\right)^{3} e^{\left(\left(\frac{T}{300}-1\right) \frac{E_{g}}{n V_{t}}\right)}
$$

The short-circuit current $I_{\mathrm{ph}}$ is also temperature- and illumination-dependent and can be expressed as:

$$
I_{p h}=I_{p h 0}\left(1+\alpha_{I}\left(T-T_{0}\right)\right) \frac{G}{G_{0}}
$$

where $\alpha_{I}$ is temperature coefficient of the short-circuit current (assumed $0.0006 / \mathrm{K}$ ) with $I_{p h 0}$ is the short-circuit current at standard test conditions (STC) i.e., $T_{0}=25^{\circ} \mathrm{C}, \mathrm{AM}=1.5$, and radiation $G_{0}=1000 \mathrm{~W} / \mathrm{m}^{2}$. The band gap $E_{\mathrm{g}}$ also decreases as the temperature increases $[30,31]$ as follows:

$$
E_{g}=1.16-7.02 \times 10^{-4}\left(\frac{T^{2}}{T-1108}\right)
$$

\section{Discussion and Results}

To validate our modified model for the PV module equivalent-circuit, we calculate the current/voltage $(I / V)$ characteristics for a PV module by applying both the standard model (Equation (7)) and the modified model (Equation (6)). The parameters of $N$ identical series-connected PV cells used to calculate the $I / V$ characteristics are listed in Table 1. The PV module is assumed to consist of 36 series-connected cells where each cell has an area of $100 \mathrm{~cm}^{2}$. 
Table 1. Parameters of $N$ identical series-connected PV cells used to calculate the $I / V$ characteristics.

\begin{tabular}{cc}
\hline & Cells 1-N \\
\hline Number of series-connected cells & 36 \\
Absolute operating Temperature $(\mathrm{K})$ & 300 \\
Area of a PV cell $\left(\mathrm{cm}^{2}\right)$ & $10 \times 10$ \\
Series resistance $R s(\Omega)$ & 0.01 \\
Shunt resistance $R p(\Omega)$ & 100 \\
Ideality factor $n$ & 1.5 \\
Reverse saturation current $I_{s 0}(\mathrm{~A})$ & $1 \times 10^{-8}$ \\
Short-circuit current $I_{p h 0}(\mathrm{~A})$ & 2.7 \\
\hline
\end{tabular}

Figure 4 shows the comparison between the calculated $I / V$ characteristics of a PV module, having the parameters depicted in Table 1, using the standard model and the modified model. The result of our modified model agrees with that of the standard model and is simpler to express.

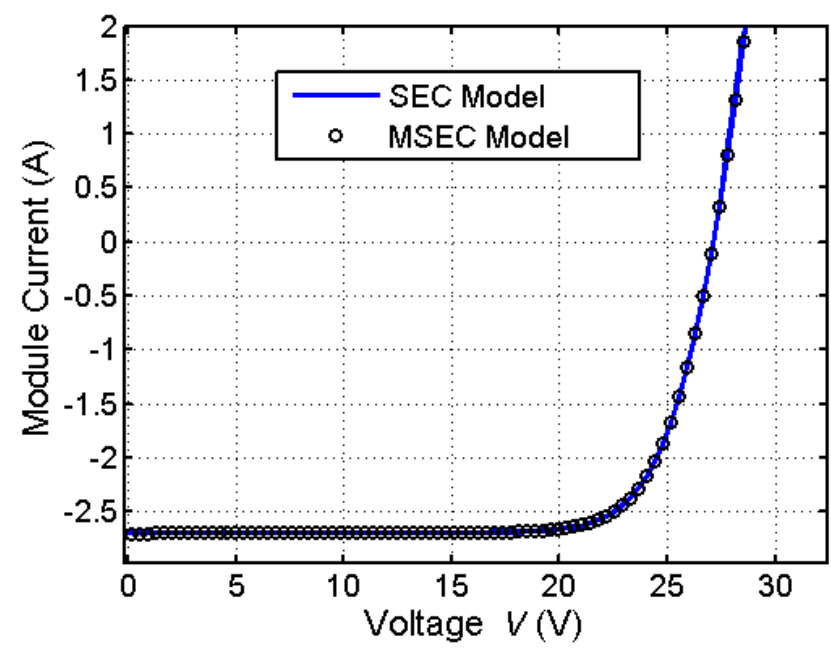

Figure 4. Calculated $I / V$ characteristics of a PV module using the standard model expressed by Equation (7) (circles) and the modified model expressed by (Equation (6)) (line).

To determine the difference between the two methods, a linear line of slope equal to 1 is plotted on the $I / V$ data calculated from both methods. The difference $\Delta$ between the calculated $I / V$ data according to both standard, $I_{\text {convtional }}$, and modified, $I_{\text {modified, }}$, models is defined as:

$$
\Delta=\sum_{i=1}^{M}\left|\frac{I_{\text {convtional }}-I_{\text {modified }}}{I_{\text {convtional }}}\right| \times 100 \%
$$

where $M$ is the length of the $I / V$ data. According to Figure 5, it equals $0.05 \%$ leading to the conclusion that our modified model of the PV cell matches the standard model.

We also measured the $I / V$ characteristics for a mono crystalline PV module consisting of $N=18$ cells. This measurement takes place at the labs of Abu Dhabi University where the operating temperature of the setup is $T=300 \mathrm{~K}$ and the lamps have an $\mathrm{AM}=1.5$-like spectrum. The measured data is modeled by the SEC model and the MSEC model by applying the fitting parameters depicted on Figure 6. Each cell of the tested PV module has an area of $5 \mathrm{~cm}^{2}$. Figure 6 shows the comparison between the calculated $I / V$ characteristics of a PV module using the SEC model (solid line) and the MSEC model (dashed line). Our modified model very well fit the measurement of the $I / V$ characteristics of the tested PV module. 


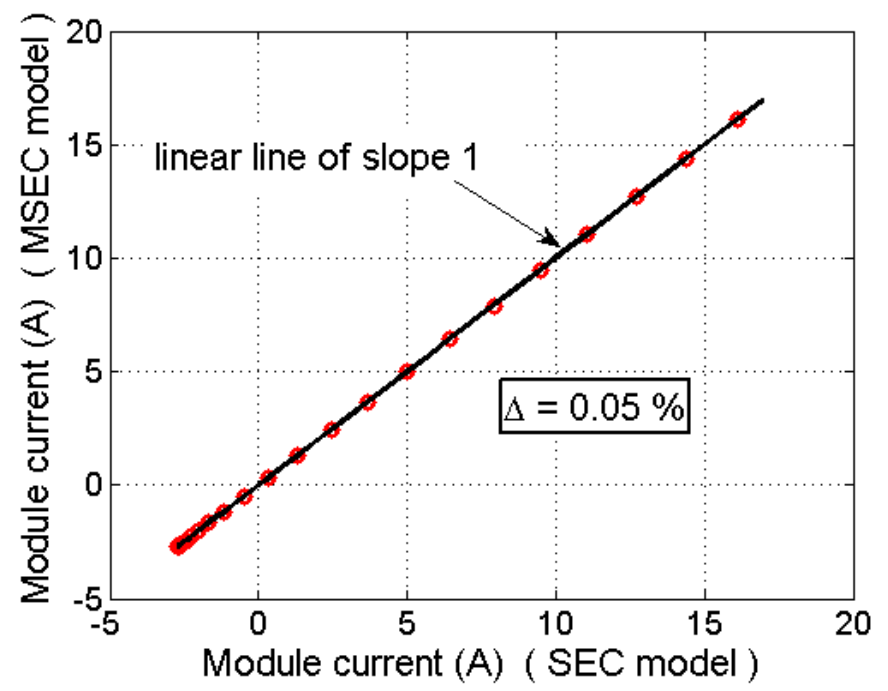

Figure 5. Calculated of $I / V$ characteristics via SEC and MSEC. The difference between the line (slope $=1$ ) and the circles is $0.05 \%$.

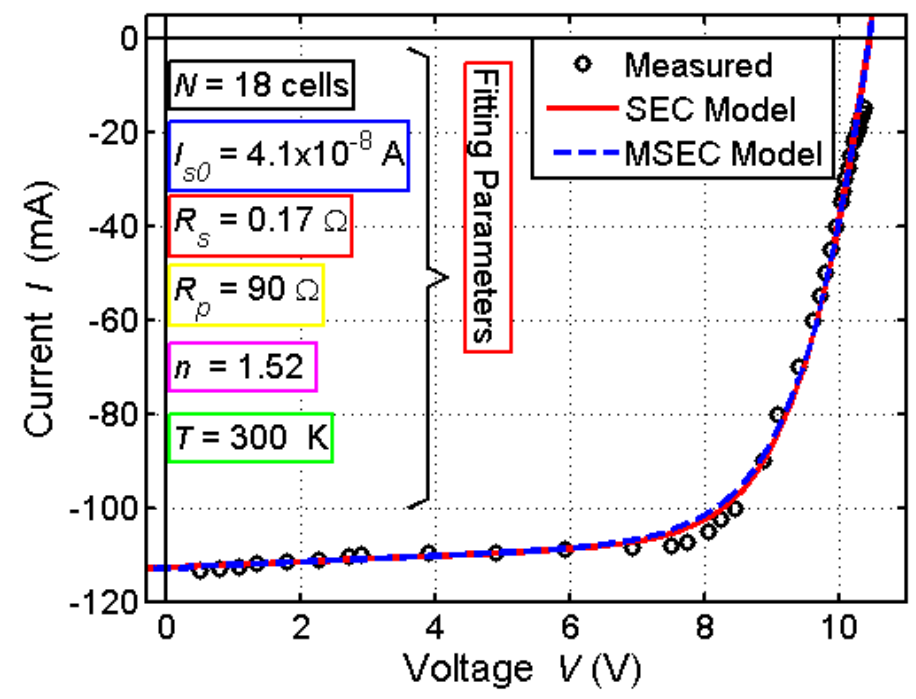

Figure 6. Measured (circles) and modeled $I / V$ characteristics of a PV module using the SEC model (solid line) and the MSEC model (dashed line).

The current/voltage $I / V$ characteristics, at different radiation levels $(G)$ and operation temperatures $(T)$, for the previous PV cell are calculated using the two models and then error function $\Delta$ is calculated. Figure 7 shows the contour plot for the error function $\Delta$ at different radiation levels $G$ and operating temperatures $T$. It can be seen in Figure 6 that the two models match very closely where the maximum value of $\Delta$ in is less than $0.053 \%$.

The modified model is again tested for different values of series resistance $\left(R_{\mathrm{S}}\right)$, parallel resistance $\left(R_{\mathrm{p}}\right)$, ideality factor $(n)$, and reverse saturation current $\left(I_{0}\right)$, as shown in Figure 8 . The resulted difference values $\Delta$ in Figure 8 are less than $1 \%$. 


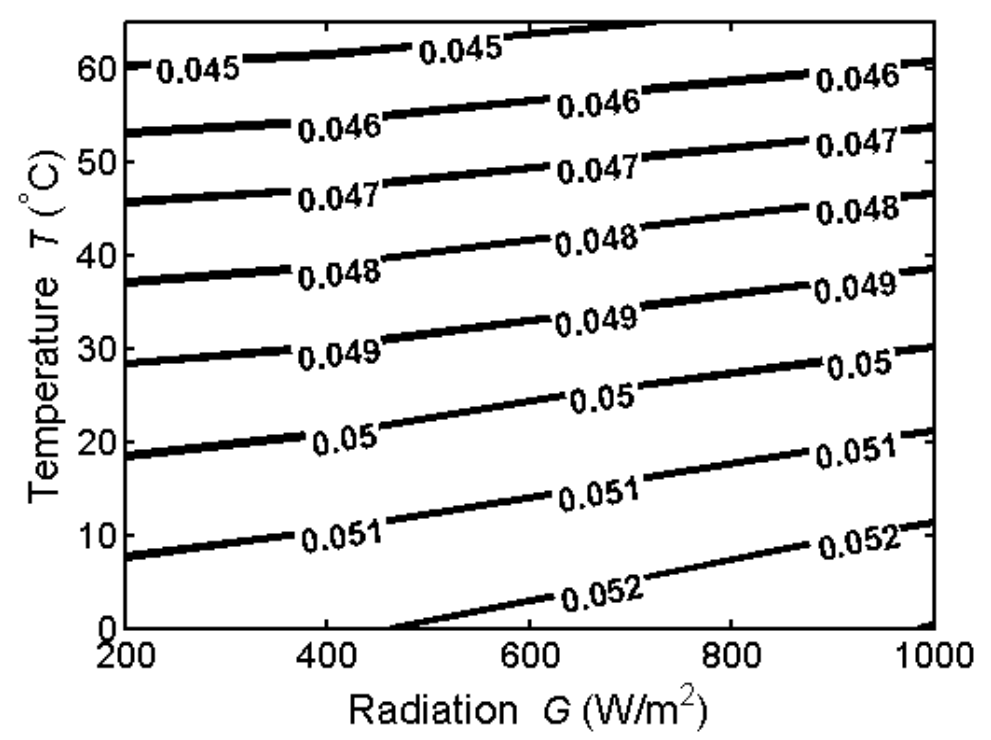

Figure 7. Contour plot of the difference $\Delta(\%)$ as a function of operating temperature $T$ and radiation levels $G$.
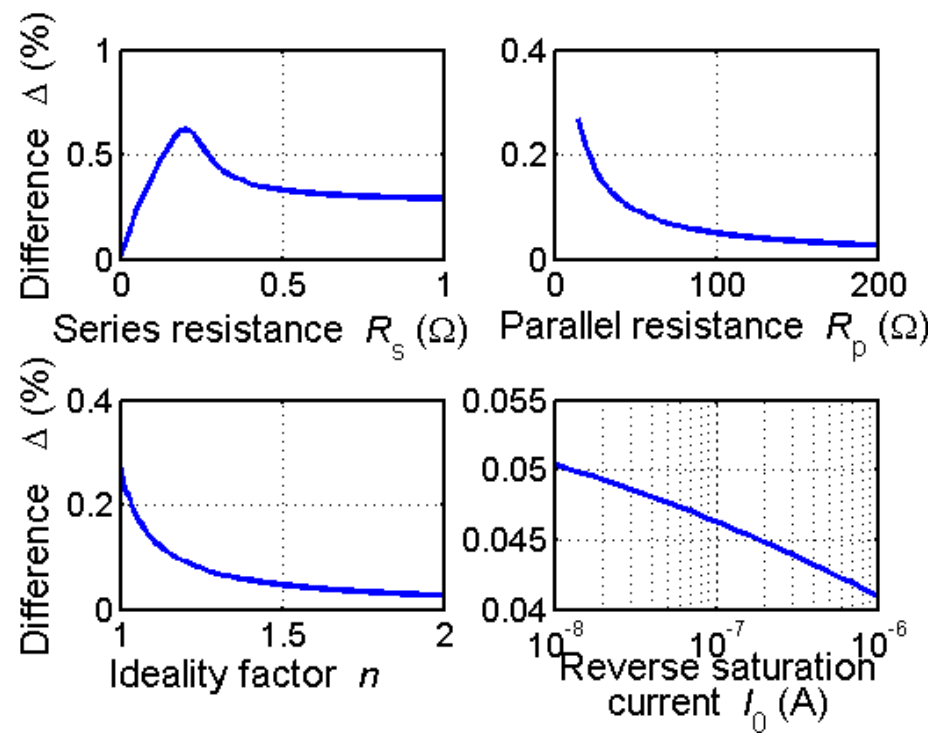

Figure 8. Difference $\Delta$ versus series resistance $\left(R_{\mathrm{S}}\right)$, parallel resistance $\left(R_{\mathrm{p}}\right)$, ideality factor $(n)$, and reverse saturation current $\left(I_{0}\right)$. The resulting difference in all cases is very small.

\section{Conclusions}

This paper presented a proposed model that modifies the standard equivalent-circuit (SEC) by removing the shunt resistance element from the standard equivalent circuit and including its effect on the diode part of the circuit. Therefore, another equivalent circuit, called here modified SEC (MSEC), results with fewer circuit elements. The current/voltage $(I / V)$ characteristics of a tested PV module were modelled by the two models under the same input variables. The calculations of the current/voltage $(I / V)$ characteristics showed that the difference between the two models is less than $1 \%$. Therefore, our proposed model can be adopted as another representation of the equivalent circuit for PV cells and modules.

Acknowledgments: The authors would like to acknowledge Abu Dhabi University for funding this work under the grant number-"19300092". 
Author Contributions: Anas Al Tarabsheh was the main investigator of this work. Muhammad Akmal and Mohammed Ghazal supported the idea of this work and proposed different techniques to make the model more accurate.

Conflicts of Interest: The authors declare no conflict of interest.

\section{References}

1. Babaa, S.; Armstrong, M.; Pickert, V. Overview of Maximum Power Point Tracking Control Methods for PV Systems. J. Power Energy Eng. 2014, 2, 59-72. [CrossRef]

2. Khalifa, M.; Saied, K.; SBitro, M.; Anwar, M.; Nizam, M. PV Power System Using Maximum Power Point Tracking (Increment Conductance Algorithm). Int. J. Innov. Res. Sci. Eng. Technol. 2014, 3, 5.

3. Vergura, S. A Complete and Simplified Datasheet-Based Model of PV Cells in Variable Environmental Conditions for Circuit Simulation. Energies 2016, 9, 326. [CrossRef]

4. Yatimi, H.; Aroudam, E. Mathematical Modeling and Simulation of Photovoltaic Power Source using Matlab/Simulink. Int. J. Innov. Appl. Stud. 2016, 16, 322-330.

5. Xiao, W.B.; Hu, F.Y.; Zhang, H.M.; Wu, H.M. Experimental Investigation of the Effects of Partial Shading on Photovoltaic Cells' Electrical Parameters. Int. J. Photoenergy 2015, 2015. [CrossRef]

6. Mazouchi, M.; Jia, J.; Huo, Y. Analysis of luminescent coupling effects in $n$ series-connected multijunction solar cells. Phys. Status Solidi A 2016, 213, 941-946. [CrossRef]

7. Bauer, A.; Hanisch, J.; Ahlswede, E. An Effective Single Solar Cell Equivalent Circuit Model for Two or More Solar Cells Connected in Series. IEEE J. Photovolt. 2014, 4, 340-347. [CrossRef]

8. Kumar, A.; Parimi, A.; Rao, K. A Comparative Study of Model Based Design of PV cell in MATLAB/ Simulink/Simscape. Int. J. Adv. Trends Comput. Sci. Eng. 2014, 3, 37-42.

9. Sinha, D.; Das, A.; Dhak, D.; Sadhu, P. Equivalent circuit configuration for solar PV cell. In Proceedings of the 1st International Conference on Non-Conventional Energy, Kalyani, India, 16-17 January 2014.

10. Bay, L.; West, K. An equivalent circuit approach to the modelling of the dynamics of dye sensitized solar cells. Sol. Energy Mater. Sol. Cells 2005, 87, 613-628. [CrossRef]

11. Castañer, L.; Silvestre, S. Modeling of Photovoltaic Cell Using Free Software Application for Training and Design Circuit in Photovoltaic Solar Energy; John Wiley and Sons Ltd.: Chichester, UK, 2002.

12. Altas, I.H.; Sharaf, A.M.I. Array Simulation Model for Matlab-Simulink GUI Environment. In Proceedings of the European Photovoltaic Solar Energy Conference, Glasgow, UK, May 2000.

13. Gray, J.L. The Physics of the Solar Cell. In Handbook of Photovoltaic Science and Engineering; Luque, A., Hegedus, S., Eds.; John Wiley and Sons: Chichester, UK, 2011.

14. Romero, B.; del Pozo, G.; Arredondo, B. Exact analytical solution of a two diode circuit model for organic solar cells showing S-shape using Lambert W-functions. Sol. Energy 2012, 86, 3026-3029. [CrossRef]

15. Del Pozo, G.; Romero, B.; Arredondo, B. Evolution with annealing of solar cell parameters modelling the S-shape of the current-voltage characteristic. Sol. Energy Mater. Sol. Cells 2012, 104, 81-86. [CrossRef]

16. Ding, K.; Zhang, J.; Bian, X.; Xu, J. A simplified model for photovoltaic modules based on improved translation equations. Sol. Energy 2014, 101, 40-52. [CrossRef]

17. Anku, N.; Adu-Gyamfi, D.; Kankam, A.; Takyi, A.; Amponsah, R. A Model for Photovoltaic Module Optimisation. J. Mech. Eng. Autom. 2015, 5, 72-79.

18. Jazayeri, M.; Uysal, S.; Jazayeri, K. A simple MATLAB/Simulink simulation for PV modules based on one-diode model. In Proceedings of the International Conference on 10th IEEE High Capacity Optical Networks and Enabling Technologies (HONET-CNS), Magosa, Cyprus, 11-13 December 2013.

19. Bikaneria, J.; Joshi, S.; Joshi, A.R. Modeling and Simulation of PV Cell using One-diode model. Int. J. Sci. Res. Publ. 2013, 3, 1-4.

20. Edouard, M.; Njomo, D. Mathematical Modeling and Digital Simulation of PV Solar Panel using MATLAB Software. Int. J. Emerg. Technol. Adv. Eng. 2013, 3, 24-32.

21. Santos, R.; Gaspar, P.D. Computational tool for simulating the performance of photovoltaic panels. In Proceedings of the International Conference on Engineering UBI-University of Beira Interior, Covilhã, Portugal, 28-30 November 2011.

22. Wang, Y.; Sheu, R. A New Piecewise Linear Circuit Model for Photovoltaic Cells and Modules. Int. J. Electr. Eng. 2015, 22, 181-188. 
23. Hsu, P.-C. Modelling of solar cells and modules using piecewise linear parallel branches. Renew. Power Gener. 2011, 5, 215-222.

24. Al Tarabsheh, A.; Etier, I.; Widyan, M. Investigating the Shunting Effects of Parallel-Connected A-Si:H Solar Cells. Int. J. Sustain. Energy 2011, 32, 71-77. [CrossRef]

25. Chander, S.; Purohit, A.; Sharma, A.; Arvindc, S.P.; Nehra, M.S.D. A study on photovoltaic parameters of mono-crystalline silicon solar cell with cell temperature. Energy Rep. 2015, 1, 104-109. [CrossRef]

26. Sharma, V.; Chandel, S.S. Performance and degradation analysis for long term reliability of solar photovoltaic systems: A review. Renew. Sustain. Energy Rev. 2013, 27, 753-767. [CrossRef]

27. Wuerfel, U.; Neher, D.; Spies, A.; Albrecht, S. Impact of charge transport on current-voltage characteristics and power-conversion efficiency of organic solar cells. Nat. Commun. 2015, 6, 6951. [CrossRef] [PubMed]

28. De Soto, W.; Klein, S.A. Improvement and validation of a model for photovoltaic array performance. Sol. Energy 2006, 80, 78-88. [CrossRef]

29. Al Tarabsheh, A. Description of the Ideality Factor of a-Si:H Photovoltaic Cells Under Different Illumination Intensity Levels. J. Renew. Sustain. Energy 2015, 7. [CrossRef]

30. Kim, S.; Jeon, J.H.; Cho, C.H.; Kim, E.S.; Ahn, J.B. Modeling and simulation of a grid-connected PV generation system for electromagnetic transient analysis. Sol. Energy 2009, 83, 664-678. [CrossRef]

31. Singh, P.; Ravindra, N.M. Temperature dependence of solar cell performance-An analysis. Sol. Energy Mater. Sol. Cells 2012, 101, 36-45. [CrossRef]

(C) 2017 by the authors. Licensee MDPI, Basel, Switzerland. This article is an open access article distributed under the terms and conditions of the Creative Commons Attribution (CC BY) license (http:/ / creativecommons.org/licenses/by/4.0/). 